\title{
The influence of wear particles in the expression of osteoclastogenesis factors by osteoblasts
}

\author{
Dominique P. Pioletti ${ }^{\mathrm{a}, \mathrm{b}, *}$, Arlette Kottelat ${ }^{\mathrm{a}}$ \\ ${ }^{a}$ Bone Bioengineering Group, Center for Orthopedic Research, Swiss Federal Institute of Technology Lausanne, EPFL, CH-1015 Lausanne, Switzerland \\ ${ }^{\mathrm{b}}$ Hôpital Orthopédique de la Suisse Romande, Lausanne, Switzerland
}

Received 11 December 2003; accepted 27 January 2004

\begin{abstract}
Orthopedic implant failures are often associated with peri-implant osteolysis. Particles generated from the wear process have been suspected to play an important role in this situation. Indeed, the peri-implant osteolysis could be due to the presence of particles stimulating the osteoclastogenesis process. We hypothesize then that the presence of a low particle concentration positively influences osteoblasts to produce osteoclastogenesis factors. If true, this hypothesis would then support the idea that the particles could be at the origin of the process leading to implant loosening. To check the validity of this hypothesis, we quantified in vitro the production of different genes involved in the osteoclastogenesis process using primary isolated human osteoblasts treated or not with particles. Results showed that low concentrations of particles might have a stimulating effect on osteoblasts to produce osteoclastogenesis factors as demonstrated by the increase of RANKL and CSF-1 gene expression in the particle group.
\end{abstract}

(C) 2004 Elsevier Ltd. All rights reserved.

Keywords: Orthopedic wear particles; Osteolysis; Osteoblast; RANKL; OPG; CSF-1

\section{Introduction}

Due to its mechanical design, an artificial joint is inevitably subjected to a wear process that generates particles. Depending on the materials used, large amount of particles can be created at the different interfaces of the implant [1]. These particles are in direct contact to the cells located in the peri-implant bone.

The presence of wear particles can activate an inflammatory cascade resulting in a bone resorption process [2-4]. This process can finally lead to the aseptic loosening of artificial joints, the major cause of implant failures [1,5].

Recently, wear particles were also shown to have an adverse effect on bone formation [6,7]. Titanium (Ti) particles downregulated the gene expression of type I collagen [8], while UHMWPE particles were shown to affect osteoblast differentiation [9]. We showed that

\footnotetext{
*Corresponding author. Bone Bioengineering Group, Center for Orthopedic Research, Swiss Federal Institute of Technology Lausanne, EPFL, CH-1015 Lausanne, Switzerland. Tel.: +41-21-6938341; fax: 41-21-693-8660.

E-mail address: dominique.pioletti@epfl.ch (D.P. Pioletti).
}

particles had a cytotoxic effect [10], modulated the fibronectin gene expression [11], and decreased the adhesion strength [12] of osteoblasts. Moreover, combination of particles and cytokines had a synergic effect on the production of inflammatory factors [13]. Using microarray techniques, it has been shown that particles had a profound impact on genes coding for inflammatory cytokines and genes controlling the nuclear architecture [14]. Nevertheless, little information is available regarding the effect of particles on osteoclastogenetic factors produced by osteoblasts. Moreover, previous in vitro studies used relatively high concentrations of particles that could correspond to an already advanced situation in the loosening process of the implant [15].

The peri-implant osteolysis is a degenerating process that can start when low concentrations of particles are present. Over years of wear process, an accumulation of particles occurs [15]. It is still under debate if the periimplant osteolysis is due either to an initial mechanical instability increasing the amount of generated particles and leading to loosening [16] or to an initial biological reaction of cells to particles leading to osteolysis and then mechanical instability [17]. It is then of interest to 
determine if low concentrations of particles, representing an early post-operative situation, can affect the bone remodeling process and more specifically the osteoclastogenesis factors produced by osteoblasts.

It has been recognized that wear particles debris are potent stimuli for osteoclast differentiation and mature osteoclast function [18]. However, only recently osteoblasts have been recognized to play a pivotal role in osteoclastogenesis process through the production of molecular factors such as RANKL, OPG, or CSF-1 [1923]. Based on this new information, it has been shown that RANKL is essential to mediate the osteoclastogenic effect of PMMA [24]. In another study, OPG inhibited in vitro murine osteoclast formation induced by fluid from failed total hip arthroplasties [25]. In peri-implant tissues of patients with implant failure, high levels of RANKL was found compared to healthy subjects [26]. Macrophages were shown to be responsible for this increase.

The goal of this study is to simultaneously quantify the levels of RANKL, OPG, CSF-1 when osteoblasts are challenged with low concentrations of particles. This information would then be useful to determine if particles may be at the origin of the peri-implant osteolysis through an induction of osteoclastogenesis. The quantification of particles effect on the osteoclastogenesis process can be helpful in the search for therapeutic treatments to control the bone remodeling around orthopedic implants.

\section{Materials and methods}

\subsection{Ti particles}

The Ti particles were purchased from Johnson Mattey company (Karlsruhe, Germany). The distribution of particle size was performed with laser diffraction by using Malvern MasterSizer equipment. The average particle size was $4.5 \mu \mathrm{m}$ and the surface area was $0.5 \mathrm{~m}^{2} /$ $\mathrm{mg}$. The particles, autoclave at $135^{\circ} \mathrm{C}$ for $15 \mathrm{~min}$, were mixed with the culture medium under sterile conditions. Based on a particle weight to medium volume ratio, a concentration of $0.01 \% \mathrm{Ti}$ particles was prepared. One milliliter of particles suspension of $0.01 \%$ contained approximately 60,000 particles. The Ti suspensions were sonicated for $30 \mathrm{~min}$ in sealed sterile container before being added to the cell culture. Endotoxin contamination of particles was excluded by limulus assay (QCL1000 Chromogenic LAL, BioWhittaker, Emerainville, France). When compared to previous in vitro studies $[8,10,27]$, the present particle concentration can be considered as low. Comparison with in vivo situation is difficult to perform. It can be estimated that the level of $30 \mu \mathrm{g} / \mathrm{ml}$ of particles used in the present study is relatively low in comparison to the mean titanium level of $1616 \mu \mathrm{g} / \mathrm{g}$ of dry tissue obtained in the surrounding of implant [15].

\subsection{Cells}

Primary human osteoblastic cells were isolated from pieces of human trabecular bone obtained from a patient (male 63-years-old) undergoing a total hip arthroplasty as previously described [28]. The pieces of bone were minced into $1 \mathrm{~mm}^{3}$ pieces, washed three times with sterile PBS, seeded into $25 \mathrm{~cm}^{2}$ tissue culture flasks and finally cultured at $37^{\circ} \mathrm{C}$ and $5 \% \mathrm{CO}_{2}$ in Dulbecco's Modified Eagle Medium (Sigma, Buchs, Switzerland) containing $10 \%$ of fetal bovine serum (Sigma), and $1 \%$ of PSF $(100 \times, 10,000 \mathrm{U} / \mathrm{ml}$ penicillin, $10,000 \mu \mathrm{g} / \mathrm{ml}$ strepzin, $25 \mu \mathrm{g} / \mathrm{ml}$ fungizone) (GibcoBRL, New York, USA). The medium was changed twice weekly. A confluent monolayer was obtained after 2-3 weeks. The cells were then transferred by trypsinization to a $75 \mathrm{~cm}^{2}$ tissue culture flask defining the cell passage number 2. These cells displayed typical phenotypes of osteoblasts as the polygonal morphology, the formation of calcium phosphate salts, the production of alkaline phosphatase, or the increase of osteocalcin production when these cells were cultured with $1,25(\mathrm{OH})_{2} \mathrm{D}_{3}[29,30]$.

\subsection{Culture conditions}

The isolated osteoblasts (passage 2-4) were seeded onto six well plates at a concentration of 750,000 cells/ well and were incubated $4 \mathrm{~h}$. The medium was removed and new medium was added with $0.01 \%$ Ti particles suspension or without particles (control). At 8, 24, 48, and $72 \mathrm{~h}$, medium was removed, cells were rinsed twice with PBS and the plates were frozen at $-80^{\circ} \mathrm{C}$ until RNA isolation.

\subsection{Gene expression measurements}

Total RNA was isolated and purified with NucleoSpin columns (Macherey-Nagel, Düren, Germany). The isolated RNA was reverse transcripted with the StratScript enzyme (Stratagene, San Diego, USA). Quantitative real time RT-PCR (ABI Prism 7700, Applied Biosystem, Foster City, USA) was performed using Amplifluor Universal Detection System (Intergen, Purchase, USA). We quantified the genes expression of procollagen type I $\alpha 1$, procollagen type I $\alpha 2$, RANKL, CSF-1 and OPG. The list of primers for the selected genes is reported in Table 1. Preliminary experiments allowed us to verify that RANKL and OPG were upregulated when osteoblasts are cultured with osteotrophic factors such $1,25(\mathrm{OH})_{2} \mathrm{D}_{3}$ or dexamethasone (data not shown) as described in the literature, e.g. [31]. We normalized the different samples by the geometric mean of three housekeeping genes (Ubiquitin C, 
Table 1

Primers used for the selected human genes

\begin{tabular}{lll}
\hline${\text { Gene name }(\text { Acc })^{\mathrm{a}}}^{\mathrm{a}}$ & ${\text { Forward } \text { primer }^{\mathrm{b}}\left(5^{\prime}-3^{\prime}\right)}$ Reverse primer $\left(5^{\prime}-3^{\prime}\right)$ \\
\hline Collagen type I $\alpha 1(\mathrm{Z} 74615)$ & CTC CTC AAG GGC TCC AAC G & CAT CGA CAG TGA CGC TGT AGG T \\
Collagen type I $\alpha 2(\mathrm{~J} 03464)$ & GAT TGA GAC CCT TCT TAC TCC TGA A & TGG GTG GCT GAG TCT CAA GTC \\
RANKL (AF053712) & CCA AGT ATT GGT CAG GGA ATT CTG & GAG ACC TCG ATG CTG ATT TCC T \\
CSF-1 (M37435) & GCA ACT TCC TCT CAG CAT CTT CTC & GCA AGG CTG TAG CAG TTA CAT CTG \\
OPG (NP_002537) & ATG CAA ACC CAG TGA CCA GAT C & AAG GTG TCT TGG TCG CCA TT \\
Ubiquitin C (NM_021009) & ATT TGG GTC GCG GTT CTT G & TGC CTT GAC ATT CTC GAT GGT \\
Ribosomal protein L13a (NM_012423) & ATC CCA CCG CCC TAC GA & TTC AGA CGC ACG ACC TTG AG \\
GAPDH (NM_002046) & CCA CCC ATG GCA AAT TCC & TGG GAT TTC CAT TGA TGA CAA G \\
\hline
\end{tabular}

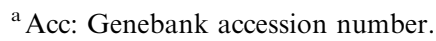

${ }^{\mathrm{b}}$ Using Amplifluor Universal Detection System, a Z sequence (ACT GAA CCT GAC CGT ACA) has to be added to the $5^{\prime}$ of each Forward Primer. This technique furnishes a specific amplification without the need for a probe.

Ribosomal protein L13a, and GAPDH). The geometric mean of at least three stable housekeeping genes was shown to give an accurate normalization for real time RT-PCR [32]. The determination of the three stable housekeeping genes was performed in a preliminary study (data not shown) where the gene expression variation between control and $\mathrm{Ti}$ group of six potential housekeeping genes was evaluated at the different time points. As we were interested by the relative gene expression between control and $\mathrm{Ti}$ group, the gene expression was further normalized by the expression of the control group. Each experiment was performed three times with gene expression measurements in duplicate.

\subsection{Statistical analysis}

A student $t$-test was used to analyze the mean variance of the data. A $95 \%$ confidence level was selected to define significance for all statistical tests.

\section{Results}

At each time point, RANKL gene expression by osteoblasts was higher in the $\mathrm{Ti}$ group compared to control, with statistical significances at 24 and $48 \mathrm{~h}$ $(p<0.01)$ (Fig. 1). A steady increase was observed from 8 to $48 \mathrm{~h}$ followed by a decrease at $72 \mathrm{~h}$. A similar trend was found for the CSF-1 gene expression by osteoblasts with a statistical significance at $48 \mathrm{~h}(p<0.01)$. OPG gene expression was slightly higher for the $\mathrm{Ti}$ group compared to control until $48 \mathrm{~h}$, however without statistical significance. The presence of low amount of $\mathrm{Ti}$ particles seems then to favor the production of osteoclastogenesis factors by osteoblasts.

Regarding the procollagen type I $\alpha 1$ gene expression by osteoblasts, there was a trend to a higher expression for the Ti group compared to control until $48 \mathrm{~h}$ with a statistical significances at $8 \mathrm{~h}(p<0.01)$. At $72 \mathrm{~h}$, the Ti particles group had a downregulating effect on the procollagen type I $\alpha 1$ genes. The procollagen type I $\alpha 2$ gene expression by osteoblasts followed the same trend as for the procollagen type I $\alpha 1$ gene except that downregulation began at $48 \mathrm{~h}$. Interestingly, the procollagen type I $\alpha 2$ gene expression seems to be more sensitive to the presence of particles than the procollagen type I $\alpha 1$ gene.

\section{Discussion}

The peri-implant osteolysis is an important clinical problem, which can lead to orthopedic implant failure. In this study, we evaluated in vitro if the presence of a low-particles concentration could be involved in this problem by quantifying the production of osteoclastogenesis factors by osteoblasts.

Based on this study, low concentrations of Ti particles might have an important role in the peri-implant osteolysis as demonstrated by the increase of osteoblast gene expression for RANKL and CSF-1, two important factors in the osteoclastogenesis process $[19,23]$. Moreover Ti particles had no effect on the gene expression of OPG which is a secreted regulator of bone density that can act locally and systemically by negatively regulating osteoclast maturation [21]. These results might support the idea that the particles could be at the origin of the process leading to implant loosening through the process of peri-implant osteolysis. At the concentration used in this study, no cytotoxic effect has been demonstrated after $72 \mathrm{~h}$ [10]. Particles may then have an important potential to modulate the production of osteoclatogenesis factors by osteoblasts.

Beside direct effect of $\mathrm{Ti}$ particles stimulating osteoblast to produce osteoclastogenesis factors, several other possibilities may be considered in the peri-implant osteolysis problem. It has been recently shown that $\mathrm{TNF}-\alpha$ induces osteoclastogenesis by direct stimulation 

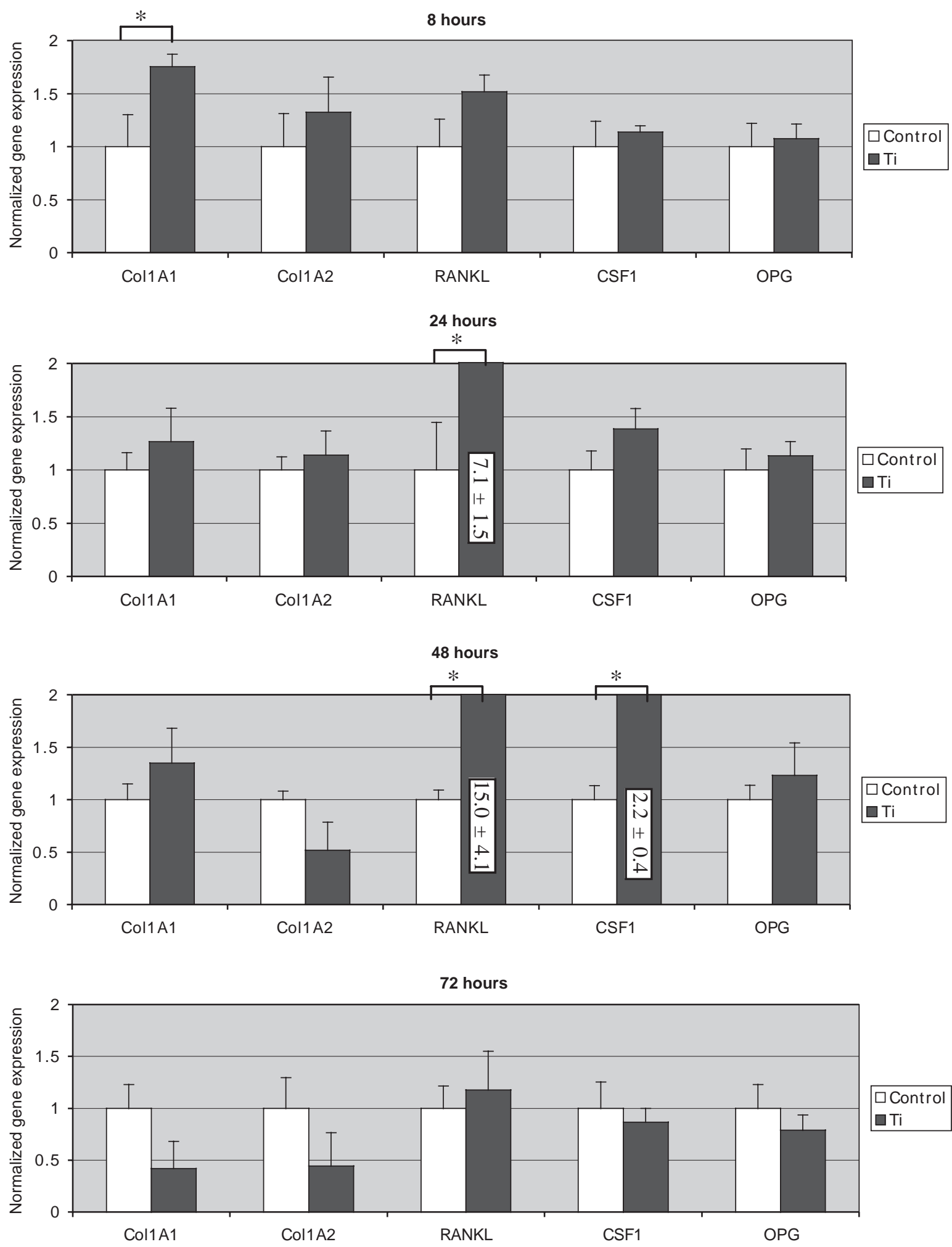

Fig. 1. Normalized gene expression of collagen type I $\alpha 1, \alpha 2$, RANKL, CSF-1, OPG for control (open) and $0.01 \% \mathrm{Ti}$ (plain) at $8,24,48$, and $72 \mathrm{~h}$. Statistical differences were found at $8 \mathrm{~h}$ for the collagen type I $\alpha 1$, at $24 \mathrm{~h}$ for RANKL, and at $48 \mathrm{~h}$ for RANKL and CSF-1 ( $n=3, p<0.01, \pm \operatorname{StDev})$.

of macrophages [33]. Particles could then also induce peri-implant osteolysis through this process. Enzymatic bone resorption through MMPs has been shown to be involved in peri-implant osteolysis [34]. Indeed, it might be possible that these different scenario (RANKL, CSF1 ; TNF- $\alpha$; MMPs) are simultaneously involved in the 
peri-implant osteolysis. Nevertheless, one of the important results of the present study was to show that low concentration of Ti particles might stimulate osteoblast to induce osteoclastogenesis and then be at the origin of the peri-implant osteolysis.

Comparison with previous in vitro studies is difficult because the particle concentrations used in the present study was much lower than in other studies or the culture conditions were different. Nevertheless, our results on collagen type I gene expression at $72 \mathrm{~h}$ is similar to a previous study using MG-63 osteoblasts [8]. Upregulation of RANKL gene expression of bone marrow cultures challenged with particles has previously been found [24]. However bone marrow cultures were maintained in osteoclastogenic conditions for several days and then exposed to particles rendering the interpretation of the particles effect on osteoclastogenesis difficult.

The results of the present study are in apparent contradiction with the work of Nakano et al. [35]. In their study, Nakano found that Ti particles inhibited RANKL expression in bone marrow cells treated with $\mathrm{PGE}_{2}$. The amount of Ti particles was similar with the present study $\left(10 \mu \mathrm{g} / \mathrm{cm}^{2}\right.$ in Nagano and $8 \mu \mathrm{g} / \mathrm{cm}^{2}$ in the present study), but the average size distribution was different $(10 \mu \mathrm{m}$ in Nagano and $4.5 \mu \mathrm{m}$ in the present study) which may explain the discrepancy in the results as size of particles has been shown to be an important parameter for cell behavior [36]. A major difference between the two studies was the addition of $\mathrm{PGE}_{2}$ in the study of Nagano. The conclusion of their study was then focused in the sense that $\mathrm{Ti}$ particles may alter the osteoclastogenesis action of $\mathrm{PGE}_{2}$. Despite different osteoblasts were used, the difference in culture condition may then explain this apparent difference in the expression of RANKL from osteoblasts challenged with Ti particles.

Most studies usually used osteoblasts obtained from cell lines [8,10,37-39], except some studies where osteoblasts were isolated from human bone pieces removed during orthopedic surgical treatment $[40,41]$. The use of osteoblasts isolated from human bone pieces, especially at the hip or knee location, represents an interesting in vitro model as it has been shown that the reaction of osteoblasts to particles may depend on the cell lines used [37].

In order to protect the peri-implant bone from osteolysis, it would then be a reasonable approach to control the osteoclastogenesis as RANKL seems to be upregulated even at low-particles conditions. With this strategy, it has been proposed to use OPG in order to decrease the bone resorption when particles are present $[42,43]$. The delivery of OPG could be done through gene therapy [44] or could be locally delivered as it has been recently proposed to use the orthopedic implant as drug delivery system [45].

\section{Conclusions}

This study suggests that particles at low concentrations could be involved in the osteoclastogenesis process as shown by the upregulation of RANKL and CSF-1 in ostoeblasts challenged with Ti particles. The Ti particles may then be at the origin of the peri-implant osteolysis and early control of osteoclastogenesis could be a potential solution to decrease this problem.

\section{Acknowledgements}

This work was supported by a grant (\#309) from the Leenaards Foundation.

\section{References}

[1] Friedman RJ, Black J, Galante JO, Jacobs JJ, Skinner HB. Current concepts in orthopaedics biomaterials and implant fixation. J Bone Jt Surg 1993;75-A:1086-109.

[2] Glant TT, Jacobs JJ, Molna'r G, Shanbhag AS, Valyon M, Galante JO. Bone-resorption activity of particulate-stimulated macrophages. J Bone Miner Res 1993;8:1071-9.

[3] Goodman SB, Huie P, Song Y, Lee K, Doshi A, Rushdieh B, Woolson S, Maloney W, Schurman D, Sibley R. Loosening and osteolysis of cemented joint arthroplasties. Clin Orthop Rel Res 1997;337:149-63.

[4] Shanbhag AS, Macaulay W, Stefanovic-Racic M, Rubash HE. Nitric oxide release by macrophages in response to particulate wear debris. J Biomed Mater Res 1998;5:497-503.

[5] Clarke IC, Campbell P, Kossovsky N. Debris-mediated osteolysis - a cascade phenomenon involving motion, wear, particulates, macrophage induction, and bone lysis. In: St John KR, editor. Particulate debris from medical implants: mechanisms of formation and biological consequences, ASTM STP 1144. Philadelphia: American Society for Testing and Materials; 1992. p. 7-26.

[6] Vermes C, Glant TT, Hallab NJ, Fritz EA, Roebuck KA, Jacobs JJ. The potential role of the osteoblast in the development of periprosthetic osteolysis: review of in vitro osteoblast responses to wear debris, corrosion products, and cytokines and growth factors. J Arthroplasty 2001;16:95-100.

[7] Zreiqat H, Crotti TN, Howlett CR, Capone M, Markovic B, Haynes DR. Prosthetic particles modify the expression of bonerelated proteins by human osteoblastic cells in vitro. Biomaterials 2003;24:337-46.

[8] Yao J, Cs-Szabo G, Jacobs JJ, Kuettner KE, Glant TT. Suppression of osteoblast function by titanium particles. J Bone Jt Surg 1997;79-A:107-12.

[9] Dean DD, Lohmann CH, Sylvia VL, Koster G, Liu Y, Schwartz Z, Boyan BD. Effect of polymer molecular weight and addition of calcium stearate on response of MG63 osteoblast-like cells to UHMWPE particles. J Orthop Res 2001;19:179-86.

[10] Pioletti DP, Takei H, Kwon SY, Wood D, Sung K-LP. The cytotoxic effect of titanium particles phagocytosed by osteoblasts. J Biomed Mater Res 1999;46:399-407.

[11] Pioletti DP, Takei H, Lin T, Van Landuyt P, Ma QJ, Kwon SY, Sung KLP. The effects of calcium phosphate cement particles on osteoblast functions. Biomaterials 2000;21:1103-14.

[12] Kwon SY, Takei H, Pioletti DP, Lin T, Ma QJ, Akeson WH, Wood DJ, Sung KLP. Titanium particles inhibit osteoblast 
adhesion to fibronectin-coated substrates. J Orthop Res 2000;18:203-11.

[13] Takei H, Pioletti DP, Kwon SY, Sung KL. Combined effect of titanium particles and TNF-alpha on the production of IL- 6 by osteoblast-like cells. J Biomed Mater Res 2000;52:382-7.

[14] Pioletti DP, Leoni L, Genini D, Takei H, Du P, Corbeil J. Gene expression analysis of osteoblastic cells contacted by orthopedic implant particles. J Biomed Mater Res 2002;61:408-20.

[15] Salvati EA, Betts F, Doty SB. Particulate metallic debris in cemented total hip arthroplasty. Clin Orthop 1993;293:160-73.

[16] Aspenberg P, Herbertsson P. Periprosthetic bone resorption. Particles versus movement. J Bone Jt Surg Br 1996;78:641-6.

[17] Bechtold JE, Soballe K, Lewis JL, Gustilo RB. The roles of implant motion and particulate polyethylene debris in the formation of an aggressive periprosthetic membrane. Proceedings of the 41st ORS, 1995. p. 767.

[18] Maloney WJ, Smith RL. Periprosthetic osteolysis in total hip arthroplasty: the role of particulate wear debris. J Bone Jt Surg Am 1995;77-A:1448-61.

[19] Boyle WJ, Simonet WS, Lacey DL. Osteoclast differentiation and activation. Nature 2003;423:337-42.

[20] Kong YY, Yoshida H, Sarosi I, Tan HL, Timms E, Capparelli C, Morony S, Oliveira-dos-Santos AJ, Van G, Itie A, Khoo W, Wakeham A, Dunstan CR, Lacey DL, Mak TW, Boyle WJ, Penninger JM. OPGL is a key regulator of osteoclastogenesis, lymphocyte development and lymph-node organogenesis. Nature 1999;397:315-23.

[21] Simonet WS, Lacey DL, Dunstan CR, Kelley M, Chang MS, Luthy R, Nguyen HQ, Wooden S, Bennett L, Boone T, Shimamoto G, DeRose M, Elliott R, Colombero A, Tan HL, Trail G, Sullivan J, Davy E, Bucay N, Renshaw-Gegg L, Hughes TM, Hill D, Pattison W, Campbell P, Boyle WJ, et al. Osteoprotegerin: a novel secreted protein involved in the regulation of bone density. Cell 1997;89:309-19.

[22] Fuller K, Owens JM, Jagger CJ, Wilson A, Moss R, Chambers TJ. Macrophage colony-stimulating factor stimulates survival and chemotactic behavior in isolated osteoclasts. J Exp Med 1993;178:1733-44.

[23] Lacey DL, Timms E, Tan HL, Kelley MJ, Dunstan CR, Burgess T, Elliott R, Colombero A, Elliott G, Scully S, Hsu H, Sullivan J, Hawkins N, Davy E, Capparelli C, Eli A, Qian YX, Kaufman S, Sarosi I, Shalhoub V, Senaldi G, Guo J, Delaney J, Boyle WJ. Osteoprotegerin ligand is a cytokine that regulates osteoclast differentiation and activation. Cell 1998;93:165-76.

[24] Clohisy JC, Frazier E, Hirayama T, Abu-Amer Y. RANKL is an essential cytokine mediator of polymethylmethacrylate particleinduced osteoclastogenesis. J Orthop Res 2003;21:202-12.

[25] Kim KJ, Kotake S, Udagawa N, Ida H, Ishii M, Takei I, Kubo T, Takagi M. Osteoprotegerin inhibits in vitro mouse osteoclast formation induced by joint fluid from failed total hip arthroplasty. J Biomed Mater Res 2001;58:393-400.

[26] Crotti TN, Smith MD, Findlay DM, Zreiqat H, Ahern MJ, Weedon H, Hatzinikolous G, Capone M, Holding C, Haynes DR. Factors regulating osteoclast formation in human tissues adjacent to peri-implant bone loss: expression of receptor activator NFkappaB, RANK ligand and osteoprotegerin. Biomaterials 2004;25:565-73.

[27] Lohmann CH, Schwartz Z, Koster G, Jahn U, Buchhorn GH, MacDougall MJ, Casasola D, Liu Y, Sylvia VL, Dean DD, Boyan BD. Phagocytosis of wear debris by osteoblasts affects differentiation and local factor production in a manner dependent on particle composition. Biomaterials 2000;21:551-61.

[28] Beresford JN, Gallagher JA, Poser JW, Russell RG. Production of osteocalcin by human bone cells in vitro. Effects of
1,25(OH)2D3, 24,25(OH)2D3, parathyroid hormone, and glucocorticoids. Metab Bone Dis Relat Res 1984;5:229-34.

[29] Puleo DA, Holleran LA, Doremus RH, Bizios R. Osteoblast responses to orthopedic implant materials in vitro. J Biomed Mater Res 1991;25:711-23.

[30] Stringa E, Filanti C, Giunciuglio D, Albini A, Manduca P. Osteoblastic cells from rat long bone. I. Characterization of their differentiation in culture. Bone 1995;16:663-70.

[31] Hofbauer LC, Khosla S, Dunstan CR, Lacey DL, Boyle WJ, Riggs BL. The roles of osteoprotegerin and osteoprotegerin ligand in the paracrine regulation of bone resorption. $\mathbf{J}$ Bone Miner Res 2000;15:2-12.

[32] Vandesompele J, De Preter K, Pattyn F, Poppe B, Van Roy N, De Paepe A, Speleman F. Accurate normalization of real-time quantitative RT-PCR data by geometric averaging of multiple internal control genes. Genome Biol 2002;3:0034.1-0034.11.

[33] Lam J, Takeshita S, Barker JE, Kanagawa O, Ross FP, Teitelbaum SL. TNF-alpha induces osteoclastogenesis by direct stimulation of macrophages exposed to permissive levels of RANK ligand. J Clin Invest 2000;106:1481-8.

[34] Takagi M. Neutral proteinases and their inhibitors in the loosening of total hip prostheses. Acta Orthop Scand 1996;67: $1-29$.

[35] Nakano M, Tsuboi T, Kato M, Kurita K, Togari A. Inhibitory effect of titanium particles on osteoclast formation generated by treatment of mouse bone marrow cells with PGE2. Oral Dis 2003;9:77-83.

[36] Gonzalez O, Smith RL, Goodman SB. Effect of size, concentration, surface area, and volume of polymethylmethacrylate particles on human macrophages in vitro. J Biomed Mater Res 1996;30:463-73.

[37] Allen MJ, Myer BJ, Millett PJ, Rushton N. The effects of particulate cobalt, chromium and cobalt-chromium alloy on human osteoblast-like cells in vitro. J Bone Jt Surg 1997; 79-B:475-82.

[38] Gonzales JB, Purdon MA, Horowitz SM. In vitro studies on the role of titanium in aseptic loosening. Clin Orthop 1996;330: $244-50$.

[39] Horowitz SM, Gonzales JB. Inflammatory response to implant particulates in a macrophage/osteoblast coculture model. Calc Tissue Int 1996;59:392-6.

[40] Martinez ME, Medina S, del Campo MT, Garcia JA, Rodrigo A, Munuera L. Effect of polyethylene particles on human osteoblastic cell growth. Biomaterials 1998;19:183-7.

[41] Zambonin G, Colucci S, Cantatore F, Grano M. Response of human osteoblasts to polymethylmetacrylate In vitro. Calcif Tissue Int 1998;62:362-5.

[42] Childs LM, Paschalis EP, Xing L, Dougall WC, Anderson D, Boskey AL, Puzas JE, Rosier RN, O'Keefe RJ, Boyce BF, Schwarz EM. In vivo RANK signaling blockade using the receptor activator of NF- kappaB: Fc effectively prevents and ameliorates wear debris-induced osteolysis via osteoclast depletion without inhibiting osteogenesis. J Bone Miner Res 2002; 17:192-9

[43] Goater JJ, O'Keefe RJ, Rosier RN, Puzas JE, Schwarz EM. Efficacy of ex vivo OPG gene therapy in preventing wear debris induced osteolysis. J Orthop Res 2002;20:169-73.

[44] Yang SY, Mayton L, Wu B, Goater JJ, Schwarz EM, Wooley PH Adeno-associated virus-mediated osteoprotegerin gene transfer protects against particulate polyethylene-induced osteolysis in a murine model. Arthritis Rheum 2002;46:2514-23.

[45] Peter B, Pioletti DP, Terrier A, Rakotomanana L. Orthopedic implant used as a drug delivery system: a numerical study. Comput Methods Biomech Biomed Eng 2001;4:505-13. 